\title{
A fazenda assombrada: figurações da escravidão no romance Til, de José de Alencar ${ }^{I}$
}

[ Haunted Farm - the figuration of slavery in the novel "Til”, by José de Alencar.

\section{Paula Maciel Barbosa ${ }^{2}$}

RESUMO O ensaio apresenta o romance Til, de José de Alencar, examinando-o em seus aspectos formais, que revelam a matéria histórica que o embasa. Discute-se as continuidades e as diferenças do livro em relação à obra anterior do romancista. Ao trazer a ação para uma fazenda de café escravista do Segundo Reinado, e propondo-se a figurar todas as camadas sociais envolvidas no mundo da fazenda, Alencar aponta para o núcleo de todo o sistema: o café e o trabalho escravo. Com isso, o romance figura dois polos, centro e periferia - ou a casa-grande e seus arredores -, que são postos em confronto, o que projeta sobre a obra ambiguidades de todos os tipos, além de responder pela instabilidade da própria estrutura do romance. Procura-se demonstrar que a escravidão é um dado essencial da obra, ainda que a simples leitura de seu enredo não aponte diretamente para isso. - PALAVRAS-CHAVE José de Alencar, Til, romances fazendeiros, indianismo, regionalismo, escravidão. • ABSTRACT This essay aims at presenting the novel “Til”, by José de
Alencar, going over its formal aspects, which are responsible for unveiling the historical substance on which it is based. Differences and continuities of the book in relation to the previous work of the author are discussed. By bringing the action to a slave-holding coffee farm during the Brazilian "Segundo Reinado" (Second Reign) and intending to figure all social classes involved within the farm's world, Alencar points to the core of the whole system: the coffee production and the slave labour. Hence, the novel figures two poles, centre and periphery - or the "casa-grande" (Big House) and its surroundings -, which are confronted, thus projecting over the novel all kinds of ambiguities, and also accounting for the instability of the very structure of the novel. We aim at showing that the slavery is an essential element of the work, even if the mere reading of its plot does not point directly to this fact. - KEYwORDs José de Alencar, “Til”, farm novels, indianist movement, regionalism, slavery.

Recebido em I3 de setembro de 2013

Aprovado em I7 de março de $20 \mathrm{I} 4$

BaRbosa, Paula Maciel. A fazenda assombrada: figurações da escravidão no romance Til, de José de Alencar. Revista do Instituto de Estudos Brasileiros, Brasil, n. 6o, p. 55-76, abr. 2015. DoI: http://dx.doi.org/Io.II606/issn.23I6-90IX.voi6op55-76

I Este ensaio retoma algumas formulações desenvolvidas em: BARBOSA, Paula Maciel. O Idílio Degradado: um Estudo do Romance Til, de José de Alencar. Tese de doutorado em Literatura Brasileira, São Paulo, Faculdade de Filosofia, Letras e Ciências Humanas da Universidade de São Paulo, 20I2, orientada por José Antonio Pasta Jr.

2 Universidade de São Paulo (USP, São Paulo, SP, Brasil). 
A sujeição violenta em que se encontra o escravo, bem como a relação de dependência à qual o homem livre e pobre na ordem escravista não pode fugir, ambas têm como antagonista, no polo oposto, a camada de homens que a propriedade insere no mundo do cálculo econômico. ${ }^{3}$

Til, de José de Alencar, publicado em $1872^{4}$, é um dos romances menos conhecidos do autor. Tendo como cenário uma fazenda de café no interior paulista em meados do século XIX, esse romance costuma receber a rubrica de "regionalista". O próprio Alencar contribuiu para tal classificação, uma vez que, em prefácio de I872, no qual sistematiza sua obra anterior, classificou o Til - além de O Tronco do Ipê e O Gaúcho - em uma categoria de livros que descrevem um Brasil tradicional e singelo. É curiosa essa definição do romance. Embora procure retratar um ambiente rural modesto e sem ostentação, o livro nada tem de singelo, se tomamos a expressão em seu sentido de inocência e de coisa constituída por apenas um material, livre de misturas. Isso porque o livro traz cenas de extrema violência e descreve uma sociedade injusta e fraturada, com dois polos sociais em confronto, o que faz dele um romance híbrido e dual.

José Veríssimo, em sua História da Literatura Brasileira, de I9I2, classifica Til - juntamente com $O$ Tronco do Ipê, O Gaúcho e O Sertanejo - como um romance de caráter pitoresco, um "romance da vida mestiça brasileira". Essa classificação será mantida e vamos encontrá-la, ainda na década de I950, na Obra Completa de José de Alencar, da Editora Aguilar, onde esses quatro livros compõem o terceiro volume e são classificados como "romances regionalistas". Na mesma década, na sua Formação da Literatura Brasileira, Antonio Candido afina a classificação ao afirmar que "O Tronco do Ipê e Til inauguram o romance fazendeiro, a descrição da vida rural já marcada pelas influências urbanas”.

3 SCHWARZ, Roberto. Um seminário de Marx. In: Sequências Brasileiras. São Paulo, Companhia das Letras, I999, p. 97.

4 Antes da publicação em volume, pela Garnier, o romance saiu em folhetins, entre 2I de novembro de I87I e 20 de março de I872, no jornal A República, vinculado ao recém-criado Partido Republicano.

5 VERÍsSIMO, José. História da Literatura Brasileira. Rio de Janeiro, Francisco Alves, I929, p. 273.

6 CANDIDO, Antonio. Os Três Alencares. In: Formação da Literatura Brasileira. Belo Horizonte/Rio 
Essa última classificação é bem adequada, uma vez que os dois romances que o crítico chama de fazendeiros mantêm entre si muitos paralelos, entre eles o de fixar a polaridade rural-urbano, tendo em seu desfecho a mudança dos proprietários, da fazenda para a cidade. Publicados no mesmo ano da Lei do Ventre Livre (se consideramos a publicação do Til em folhetins), I87I, ambos os livros tratam da escravidão, mesmo - ou especificamente - que de forma enviesada. O confronto desses livros, em suas coincidências e discrepâncias, ajuda a iluminar aspectos de cada um deles. Nos dois romances fazendeiros, os protagonistas são órfãos que procuram deslindar um crime antigo associado ao proprietário da casa-grande e testemunhado por escravos do convívio dessas personagens. Em outro ponto de contato, ambos os livros tratam da dificuldade vivida pelos proprietários de grandes fazendas de café para se fixar em uma consciência encobridora da realidade, pelo fato de o ambiente da fazenda deixar mais à mostra as contradições sociais. Além disso, tratam com agudeza da dependência a que estão sujeitos os homens livres e pobres no regime escravista de produção. No entanto, se $O$ Tronco do Ipê poderia ser chamado de "romance da casa-grande", o Til poderia ser antes conhecido como "romance do terreiro". Nele, inexiste a descrição dos interiores. A história toda se passa em trânsito, pois as personagens estão frequentemente indo ou voltando de algum lugar. É como se o mundo burguês, com seus interiores confortáveis, não tivesse ainda se formado de maneira completa.

Se, nas críticas de jornal contemporâneas ao seu lançamento, o Til é bem acolhido, essa primeira impressão positiva não se mantém, e a posição estimada do livro, em relação às outras obras do autor, pode ser resumida nas palavras que abrem o estudo, de I95I, que precede o Til, na edição das obras de José de Alencar feita pela José Olympio: "Na família contraditória, excessiva, mas, afinal, fascinante que são os romances de José de Alencar, Til desempenha o ofício quase dispensável de parente pobre"7.

Essa posição de "parente pobre" e "dispensável" reflete-se na fortuna crítica do livro, que não conhece nenhum estudo de fôlego. Til é sempre citado de passagem. Talvez esse ostracismo se deva à dificuldade de classificação, na obra do autor, de um romance que trata de estratos menos privilegiados da sociedade sob nova perspectiva. Em relação aos romances anteriores, a grande novidade trazida por Til é que, nele, dá-se um confronto entre o mundo da elite e o restante da sociedade que, apesar de ser mostrado como periférico em relação ao núcleo de poder, tem no enredo do livro um papel de peso equivalente.

Uma ideia tida como certa pelos contemporâneos de Alencar, mas que foi perdendo força ao longo do século XX, é a de que a obra alencarina pode ser dividida em duas fases. A primeira terminaria com a publicação de Iracema, em I865; a segunda teria sido inaugurada com a publicação, em I870, de O Gaúcho, que Alencar assina com o pseudônimo de "Sênio". No prefácio desse livro, o romancista afirma que as desilusões teriam provocado nele uma velhice precoce, que, bem considerada, pode significar amadurecimento e mudança. O hiato de quatro anos entre Iracema

de Janeiro, Itatiaia, I993, v. II. p. 20 .

7 PIMENTEL, Osmar. Um inventor de mundo novo. In: Alencar, José de. Til - Romance Brasileiro. Rio de Janeiro, José Olympio, I955 (v. XI das Obras de Ficção de José de Alencar). 
e O Gaúcho deve-se à intensa participação política de Alencar no período, no qual também publica vários textos políticos e vem mesmo a exercer, de I868 a I870, o cargo de Ministro da Justiça. Alencar deixa a pasta desgastado e desiludido com o Imperador. Essa desilusão sempre foi apontada como a causa de mudanças nos romances da década de I870. O que se postula, aqui, é a ideia de que, menos do que às desilusões pessoais, as mudanças temáticas e formais da literatura alencarina, na década de I870, devem-se ao fato de que alguns romances se abrem para uma realidade social mais ampla e complexa do que a tratada em seus romances anteriores, que se dividiam em romances urbanos - restritos ao universo da elite e ambientados em um período pós-Independência - e históricos/indianistas - ambientados nos primeiros tempos da colonização. Os romances fazendeiros herdam dos romances indianistas alencarinos anteriores - Iracema e O Guarani - a característica de falar de "toda" a sociedade, mas, ao tratar da realidade brasileira do Segundo Reinado, aproximam-se dos romances urbanos.

Essa nova configuração ecoava um momento histórico específico: o fim dos anos de I860 é considerado pela historiografia como um período de crise que já prefigura o fim do Império ${ }^{8}$. Nesse momento, a literatura começa a figurar a escravidão de maneira mais direta, trazendo a ação das narrativas para fazendas escravistas produtivas 9 . Como já apontado, os romances fazendeiros foram escritos no auge da crise política que culminou na aprovação da Lei do Ventre Livre. Na época, os temas do trabalho, da posse da terra, da mão de obra escrava, dos homens livres e pobres estavam na ordem do dia e, como se sabe, eram preocupações de José de Alencar, que os discutiu no parlamento e em sua literatura. A figuração literária da escravidão rural, no entanto, vem acompanhada das dificuldades ideológicas que o tema trazia em seu bojo. Para dar conta dessas dificuldades, Alencar lança mão de materiais por ele já trabalhados em sua literatura anterior.

\section{DO INDIANISMO AO REGIONALISMO}

A proximidade histórica do momento tratado nas obras obriga a uma descrição mais "realista" do que a presente nas aventuras folhetinescas de O Guarani ou na aura mítica de Iracema. Ao mesmo tempo, os romances fazendeiros trazem marcas claras de sua filiação aos indianistas, principalmente a O Guarani, tendo os três livros a intenção de representar a coletividade. Neles, de forma paralela ao enredo, o autor constrói uma alegoria da nação. Valéria de Marco ressalta, em O Guarani,

8 Para uma análise do período como clivagem e princípio da decadência monárquica, ver HOLANDA, Sérgio Buarque. Crise do Regime. In: (Org.). História Geral da Civilização Brasileira, São Paulo, Difel, I969, t. II, v. 5, p. 7-I3. Para uma exposição da "experiência histórica de I87I", ver CHALHOUB, Sidney. Machado de Assis, Historiador. São Paulo, Companhia das Letras, 2003.

9 Os romances fazendeiros alencarinos não foram as únicas obras da época que trataram ficcionalmente da escravidão rural, apontando para uma nova categoria literária que dava voz a preocupações da sociedade, uma vez que o fim da escravidão estava em pauta e era discutido publicamente. (Cf. BARBOSA, op. cit., principalmente o tópico "Os romances da fazenda"). 
a descrição de uma comunidade utópica, fechada e autossuficiente, assentada em um espaço hierarquizado ${ }^{\text {To }}$. Em Til, temos algo semelhante: o livro se passa em um cenário restrito ao entorno da Fazenda das Palmas. Dentro da fazenda, a casa-grande é rodeada por senzalas e pelas casas do administrador e dos feitores. Em volta, as plantações de café e um recanto pitoresco. Fora dos domínios da fazenda, a venda de Chico Tinguá, a casa de Berta, e a casa em ruínas de Zana. Num terceiro círculo, mais afastado, e já misturado à floresta, a grota de Jão Fera. A forma pela qual as personagens são relacionadas aos lugares onde vivem, e o modo pelo qual esses lugares são hierarquizados, lembra muito a construção do espaço em O Guarani. Nos dois livros, a mesma descrição de uma comunidade fechada que, entretanto, não deixa de ter, em seu horizonte, a perspectiva de centros urbanos mais desenvolvidos, no Brasil e na Europa, como pontos de fuga. Nos dois livros, a mesma sensação de um cenário bem delimitado que pode ser lido, todavia, como alegoria da nação no seu todo, aí incluídos a representação das classes e o seu funcionamento hierárquico.

Além da concentração espacial, existe também, nos dois romances, a concentração temporal. A ação propriamente dita (descontando-se os flashbacks elucidativos) resume-se a dez dias, em O Guarani, e a algumas semanas, em Til. Outra coincidência entre as duas narrativas é o final ruinoso. O espaço central sofre um atentado e perece a fogo. No caso de Til, a casa-grande não é afetada, apenas as plantações, mas é inequívoca uma ampla desestruturação na comunidade, sucedida pela transferência dos fazendeiros para São Paulo.

Além disso, a proximidade entre as duas personagens principais de Til, Berta e Jão Fera, Iracema e Peri, respectivamente, aponta para a influência dos romances indianistas no romance fazendeiro. A crítica não foi indiferente a essa aproximação. Raimundo de Magalhães Júnior, por exemplo, classifica Jão Fera como "uma mistura grotesca de Peri com Quasímodo"II. Apesar de sua violência, a personagem é portadora de um código de honra apurado. Jão não é índio como Peri, mas certamente descendente de índio, como indicam sua tez avermelhada e seu apelido de "bugre". Seu passado é incerto e traz uma aura mítica, que o eleva. Ainda bebê, apareceu na fazenda do pai de Luís Galvão em cima de um cavalo, e ali foi criado como dependente. Sua origem mítica é reforçada por suas características excepcionais; assim como Peri, é capaz de façanhas extraordinárias. Além disso, existem muitos pontos de contato entre Peri e Jão Fera: os dois dominam de forma mítica e sobre-humana as forças da natureza, têm sangue índio e não se integram ao mundo da "casa-grande".

A moradia de Jão Fera aproxima-o muito de Peri. Ambos adaptam-se a lugares criados pela natureza para se protegerem, o que resulta em uma habitação precária e cercada de perigos: Peri à beira de um precipício, Jão embaixo de uma lasca de pedra que pode despencar a qualquer instante. É interessante notar que as duas personagens mantêm uma relação problemática com a comunidade central; no entanto, nesse aspecto, parecem fazer caminhos inversos. Peri, filho das selvas, tenta se aproximar do solar dos Mariz; Jão, criado como um agregado, afasta-se da fazenda e vai morar na floresta. De qualquer forma, o que está em pauta é a relação

Io MARCO, Valéria de. A Perda das Ilusões: o Romance Histórico de José de Alencar. Campinas, Unicamp, I993. II MAGALHÃES JR., Raimundo de. Joséde Alencar e Sua Época. Rio de Janeiro, Civilização Brasileira, I977, p. 302. 
de dependência do índio aculturado ou do mestiço, que se sentem deslocados da sociedade central e mais à vontade no sertão. Como Peri, Jão certamente é o herói do livro e sua honra vai sendo ressaltada ao longo do enredo. O capanga violento da primeira parte do livro vai se transformando em um homem honrado aos olhos do leitor, que acompanha seu drama pessoal e seu vínculo de devoção a Berta; devoção que o aproxima de Peri, devotado a Ceci. Em sentido inverso, Luís Galvão, o fazendeiro, vai perdendo ao longo do livro sua reputação ilibada e mostra-se atormentado pela culpa de um crime pretérito. A ambiguidade em relação aos papéis de herói e bandido simultaneamente desempenhados pelas duas personagens provém da ambiguidade entre a importância do centro e da periferia no romance. Essa polarização problemática da esfera da casa-grande e a de seus arredores é essencial ao livro e decorre da já citada opção autoral de figurar a população rural menos privilegiada e, também, a elite proprietária, ambas com importância no romance. Temos assim dois polos, sociais e espaciais, postos em confronto.

Como se viu anteriormente, Berta também dá desenvolvimento a núcleos temáticos já presentes nos romances indianistas alencarinos. Personagem central - o título refere-se a ela -, participa de duas dimensões que seguem paralelas: o enredo sentimental e a dimensão alegórica. Além disso, como mediadora das contradições dos dois mundos em confronto, a personagem sintetiza todas as tensões que estão em jogo. Moça pobre e dependente, moradora de um casebre fora dos domínios da fazenda, Berta se relaciona, também, com a esfera da casa-grande, e, mais do que isso, descobre, no desenrolar do enredo, que é filha do fazendeiro. Se Iracema, que traz em seu nome o anagrama de América, representa a terra, Berta, também chamada de Til por Brás, o sobrinho perverso e anormal do fazendeiro, representa, na vertente alegórica do romance, mais do que a terra, a nação, e traz em seu nome e apelido, combinados com o de Brás - que participa desta vertente do romance, juntamente com Zana - a palavra "Brasil" ${ }^{2}$. Berta e Iracema têm em comum a intimidade com a natureza: muito ágeis e corajosas, ambas se preocupam com o mundo que as rodeia. Berta, a seu modo, é uma filha de Iracema, embora não seja índia, mas mestiça. Vários indícios apontam para seu lado caboclo, mesmo que ele nunca seja explicitado. Nesse sentido, retoma uma personagem secundária de O Guarani: Isabel, a filha de D. Antônio de Mariz e de uma índia. Como Isabel, Berta é órfã de mãe e filha ilegítima do patriarca.

Como se vê, Berta e Jão Fera, os protagonistas de Til, pertencem à esfera da periferia da fazenda escravista e mantêm com os moradores da casa-grande uma relação de dependência, característica que compartilham com personagens indígenas ou mestiças dos romances indianistas. O que nos interessa apontar é o vínculo entre a mestiçagem - ainda em um nível racial e de mistura de culturas, na base da formação dos brasileiros - e a ambiguidade do lugar do dependente nos romances fazendeiros alencarinos.

Antes de Alencar, o indianismo já se estabelecera como eixo básico de nosso Romantismo e era desenvolvido com o apoio do Imperador e do Instituto Histórico e Geográfico Brasileiro. Com Gonçalves Dias, alguns núcleos temáticos se consolidaram,

I2 O que se afirma não é evidente, mas figurado como enigma a ser decifrado. Os passos dessa decifração podem ser conferidos em BARBOSA, op. cit., p. I52. 
entre eles o do mestiço sem lugar e o da grande violência de nossa história colonial. Dois estudos recentes, que tratam do Romantismo brasileiro, apontam para reflexões de Gonçalves Dias sobre essa questão. A conexão entre o indianismo e o tema do mestiço que se sente órfão e sem lugar na sociedade é levantada por Bernardo Ricupero ${ }^{\mathrm{I3}}$, que vincula a problemática do mestiço Gonçalves Dias a suas palavras em Meditação: "E os homens da raça indígena e os de cor mestiça disseram em voz alta: - E nós, que faremos? Qual será o nosso lugar entre os homens que são senhores, e os homens que são escravos?”4. David Treece, por sua vez, ressalta, além dessas, as palavras de Gonçalves Dias em suas "Reflexões sobre os Anais Históricos do Maranhão de Bernardo Pereira de Berredo”, publicadas, como Meditação, na revista Guanabara, em I849. Nelas, o poeta, depois de considerar a escravidão e o extermínio dos índios como monstruosos, analisa a posição do índio educado pelos jesuítas: "Não podemos considerar o índio no estado de catequese senão como ente de transição; [...] nesse estado o índio não era nem selvagem nem civilizado [...]; mas passando, sem preparatório, instantaneamente de um para outro estado, tornara-se igualmente incapaz de ambos - de viver nas cidades [...] ou de viver nas selvas” ${ }^{\prime 5}$.

Gonçalves Dias aponta para duas polarizações diferentes, mas que se completam e têm como consequência um espaço de indeterminação. A primeira trata da polarização entre senhores e escravos, a segunda da polarização entre as cidades e as selvas. Nos dois casos, o poeta constata a existência de uma zona intermediária, entre dois polos antagônicos, a que estariam condenados seres misturados e sem lugar. Esse complexo temático é atualizado em Til tanto na polarização espacial e social da casa-grande e de seus arredores, quanto na situação precária e ambígua de Berta e Jão Fera. A vulnerabilidade e a condição de "ente de transição" aludida por Gonçalves Dias seriam qualidades herdadas de nossa literatura de temática indianista que acabam se cristalizando no tema do dependente, considerado por Roberto Schwarz como complexo temático central na literatura brasileira ${ }^{16}$. Vinculado a esse tema poderíamos apontar também o "regime do limite" postulado por José Antonio Pasta Jr. ${ }^{\mathrm{I7}}$.

Nos romances fazendeiros, ao trazer a ação para fazendas de café escravistas do Segundo Reinado, Alencar, ao mesmo tempo em que desloca o eixo espacial para a periferia rural - se pressupomos um contraponto com o cenário de seus romances urbanos, ambientados no centro político do Império -, aponta, também, para o centro de todo o sistema, o café e o trabalho escravo, no local onde a riqueza da nação é produzida. Nesse ponto repete-se, no nível do processo social, a ambiguidade entre centro e periferia que, como já apontamos, é estrutura narrativa essencial, e

I3 RICUPERO, Bernardo. O Romantismo e a Ideia de Nação no Brasil (I830-I870). São Paulo, Martins Fontes, 2004. I4 Apud TREECE, David. Exilados, Aliados, Rebeldes - o Movimento Indianista, a Política Indianista e o Estado-nação Imperial. São Paulo, Nankin/Edusp, 2008, p.I60.

I5 Apud idem, ibidem, p. 58.

I6 Cf. SCHWARZ, Roberto. Ao Vencedor as Batatas. São Paulo, Duas Cidades, I992.

I7 Cf. PASTA JR., José Antonio. Volubilidade e Ideia Fixa (o Outro no Romance Brasileiro). Sinal de Menos. Ano 2, n. 4, 20Io. Ver também, do mesmo autor, O romance de Rosa: temas do Grande Sertão e do Brasil. Novos Estudos CEBRAP, n. 55, São Paulo, nov. I999. 
reflete-se, como veremos, na formação do ponto de vista de Til. A força simbólica desta estrutura provém, salvo engano, de sua capacidade virtual de figurar várias instâncias da realidade, inclusive a posição do Brasil como país periférico em relação à Europa. Não é à toa que Alencar tenha repetido essa estrutura em O Guarani e em seus dois romances fazendeiros, quando tenta falar do Brasil. Essa estrutura aponta também para a ambiguidade da posição da elite em relação ao seu país e aos brasileiros, sentindo-se a um só tempo "central" face ao povo brasileiro e periférica face aos centros de poder europeus ${ }^{18}$. Essa gravitação pode ser exemplificada, também, no enredo dos romances fazendeiros se pensamos que os proprietários abandonam a fazenda e vão morar na cidade, trocando a casa-grande, núcleo de um empreendimento rural produtivo e lucrativo, base da riqueza da família, pelos centros de poder político.

Em um nível mais radical, a esta ambiguidade provocada pela reversibilidade da importância de centro e periferia subjaz o descompasso entre a importância dos escravos na produção das riquezas e a sua posição de não sujeitos, uma vez que a força de trabalho dos escravos era vital para a manutenção de toda a nação. Nos romances fazendeiros, principalmente em Til, o desacordo entre a efetividade e a importância dos escravos e sua falta de autonomia, em paralelo ao poder e centralidade da elite cafeicultora e sua total dependência em relação ao trabalho escravo, é nó não explicitado como assunto, mas que comparece na formalização literária, tanto na existência da polarização das esferas da casa-grande e de seus arredores, quanto na atmosfera sombria e melancólica do romance. Poderíamos nomear esse nó como uma concepção do trabalho como uma esfera degradada ${ }^{\text {I9 }}$.

Ao tratar de tema tão essencial quanto contraditório, Alencar toca em um ponto de difícil expressão, um tabu, o que faz que o realismo pitoresco, típico do regionalismo, conviva com a descrição de uma realidade distorcida, contrária às leis naturais. Em Til, fenômenos extraordinários acontecem, apontando para uma dimensão transcendente e fantasmagórica vinculada a uma atmosfera lúgubre, na qual reinam o descontrole e a frágil autonomia das personagens dependentes - livres ou escravas -, suscetíveis, todas, a transes e a fusões com outros seres, em uma estranha transfusão de almas. Distorções formais, como a proliferação de duplos, em várias instâncias do romance - personagens, enredo, narrador -, apontam para o tempo do mito, sucedâneo da história que se repete, porque nunca superada. É isso que faz com que a dimensão do espaço seja hipertrofiada, assim como ocorre com a teia imagética, excessivamente densa, concretizando forças que pairam descontroladas ou afloram do subterrâneo. Nossa hipótese é a de que, em Til, essa esfera do mito, do descontrole e da superstição deve-se à tentativa contraditória de figuração da escravidão e de seus desdobramentos nas relações sociais.

I8 Essa gravitação problemática é estudada e desenvolvida por Roberto Schwarz em seus estudos dedicados à obra de Machado de Assis. A coexistência de ideias liberais e escravidão, baseada em nossa dualidade estrutural e responsável por todas as nossas ambivalências ideológicas, era consequência das contradições do próprio sistema planetário do capital, que se mostra de forma mais crua na periferia.

I9 Cf. CARDOSO, Adalberto. Escravidão e Sociabilidade Capitalista: um ensaio sobre inércia social. Novos Estudos CEBRAP, n. 6o, São Paulo, mar/2008. 
A "metafísica esquisita das letras nacionais" ${ }^{20}$, presente em muitas obras literárias brasileiras, em Til parece exacerbada, talvez pelo fato de o ponto de vista do romance assumir a dualidade e a indecisão entre polos, figurando o confronto entre duas esferas sociais e incorporando em sua forma todas as contradições que a escravidão colonial moderna trazia em seu bojo. Em sua dualidade formal, o romance mimetiza "as particularidades da sociedade brasileira, escravista e burguesa ao mesmo tempo"z: um dos núcleos do romance trata da sociedade vinculada à casa-grande, aproximando-se dos romances urbanos de Alencar ao tomar como assunto o namoro entre jovens e o casamento de um jovem pobre e talentoso com uma herdeira rica; outro núcleo trata da periferia da fazenda escravista e caracteriza-se, de um lado, pelo tom descritivo e pitoresco do regionalismo, de outro, pela dimensão fantasmagórica já apontada. É como se o romance ganhasse em interesse por tratar da fratura social brasileira e ousar discutir, mesmo que de forma pouco distanciada e um tanto atabalhoada, um ponto nevrálgico que naquele momento estava sendo debatido na esfera pública: a mão de obra escrava. Roberto Schwarz, em longa e importante nota a capítulo que trata da dificuldade encontrada por Alencar para formalizar a matéria local brasileira nos moldes do romance europeu de sua época, reconhece nos romances fazendeiros - que considera o ponto alto da obra alencarina - esse viés antirrealista: "São livros de intriga abstrusa, ligada a uma noção subliterária do destino e da expiação das culpas" ${ }^{2}$. Paradoxalmente, esta forma de figuração permitiria "um realismo que entre nós o Realismo de tradição literária não só não alcançava, como dificultava”23. Assim, o viés antirrealista de Til tenderia a figurar com vigor os "antagonismos objetivos do mundo da fazenda" 24 .

$\mathrm{O}$ ponto de vista narrativo do romance tem características intrigantes. $\mathrm{O}$ narrador em terceira pessoa não é imparcial: usa tons distintos quando trata das duas esferas em confronto. Isto faz com que, apesar de manter características de um narrador em terceira pessoa, que domina passado e presente, tenha também um estatuto de personagem, na medida em que sua parcialidade o aproxima dos fazendeiros do livro. Chama a atenção o fato de que as personagens principais, Berta e Jão Fera, não façam parte da esfera social mais valorizada por ele. Ambos têm plena consciência das injustiças existentes no meio social em que vivem, e a explicitam de muitas maneiras. Por seu lado, o narrador mantém sempre um tom condescendente e delicado quando trata da família de proprietários da Fazenda das Palmas. Além disso, há um descompasso esquisito entre suas afirmativas e a realidade esboçada em muitas partes do livro. Ao se ler o romance, a impressão é a de que o narrador

20 A expressão e o tema de estudo são de José Antonio Pasta Jr., que já o desenvolve há vários anos e cujo enfoque foi essencial para esta leitura de Til. Segundo o crítico, os impasses fundamentais da matéria histórica brasileira precipitam um salto para um conjunto de formas que configuram uma "metafísica" peculiar, recorrente na literatura brasileira.

2I SCHWARZ, Roberto. Um Mestre na Periferia do Capitalismo. São Paulo, Duas Cidades, I998, p. I2.

22 Idem. A Importação do Romance e Suas Contradições em Alencar. In: Ao Vencedor as Batatas. op. cit., p. 59.

23 Idem, p. 57.

24 Idem, p. 59. 
é equilibrado e almeja uma harmonia ideal, mas o mundo a sua volta foge a seu controle. As coisas teimam em acontecer à revelia, por mais que ele se esforce em manter as rédeas dos acontecimentos.

A atmosfera de perigo paira sobre todo o livro. Apesar de existir um local lúgubre, nomeado no livro como o lugar do perigo, a Ave Maria, espaço das emboscadas, trata-se aqui de um mal sem lugar e que toma aspectos diferentes ao longo do romance. Isso provoca um estranhamento, porque não se trata, apenas, do ritmo acelerado comum aos romances românticos, cujo enredo é baseado nas peripécias das personagens (o que também existe no enredo de Til), mas de afloramentos de um poder fora de controle, ligado à natureza ou ao mundo sobrenatural, e também, em muitos casos, à maldade de algumas personagens, maldade essa escorada nas difíceis relações sociais. No entanto, tal poder funciona, no livro, como um dado sempre presente, que dá origem a ações que interferem no enredo, embora pareçam fora do controle do narrador, que se mostra surpreso.

Um bom exemplo da diferença de tratamento dado, por parte do narrador, à família de fazendeiros e aos homens pobres é o capítulo "Pousada", no qual descreve a venda de Chico Tinguá, amigo de Jão Fera, com minúcia, mas de forma distanciada e preconceituosa, chamando a atenção para a modorra de seus proprietários. O descompasso entre trabalho efetivo e desprestígio deste trabalho aos olhos do narrador faz com que essa cena demonstre bem a concepção contraditória do trabalho que alicerça o romance. $O$ vendeiro é apresentado cochilando sobre o balcão. Sua companheira, Nhanica, prostrada, observa a água fervente enquanto "a louça ainda suja do serviço da véspera" se acumula à sua frente. No desenrolar da cena, a pousada vai se enchendo com moradores locais e forasteiros e o casal de vendeiros serve café e refeições para todos. Mesmo quando vai narrar um movimento produtivo de Nhanica, o narrador não deixa que o leitor se esqueça de sua presumida indolência: "Ergueu-se então a rapariga e sem espreguiçar-se; tirou da trempe a panela de feijão para deitar o boião d'água; e [...] correu a buscar água para lavar a louça”25.

Em Til, como em muitos romances regionalistas posteriores, a fala das personagens traz a marca de exotismo e peculiaridade regional, principalmente nas cenas que tratam dos homens que não são da elite nem fazem parte do núcleo de personagens pobres protagonistas. Quando trata das personagens menos importantes que povoam o romance, o narrador usa uma linguagem direta e os diálogos trazem termos regionais, como nos diálogos entre os frequentadores da venda, ou em algumas cenas no terreiro da fazenda. O relacionamento entre essas personagens do romance, entrevisto, principalmente, pelo diálogo que mantêm entre si, esboça um "espírito rixoso" ${ }^{26}$, que se desdobra em uma necessidade de encobrimento das motivações das ações, o que torna as relações interpessoais, além de violentas, dissimuladas.

25 ALENCAR, José de. Til. In: Obra Completa. Rio de Janeiro, Aguilar, I965, v. III, p. 746. Grifos meus. As próximas citações de Til virão apenas com o título do romance e o número da página.

26 Cf. OTSUKA, Edu Teruki. Espírito Rixoso: para uma Interpretação das Memórias de um Sargento de Milícias. São Paulo, Revista do IEB, n. 44, p. I05-I24, fev. 2007. 
Nessas cenas, o tom do narrador é direto e homogêneo, pois o contraste e o hibridismo que permeiam o romance são mantidos à parte quando não há o confronto das duas esferas polarizadas. O mesmo efeito ocorre, também, na esfera da elite, quando o casal de fazendeiros é apresentado. No entanto, há cenas em que as contradições são postas em presença, e nestas o contraste fica patente. Tais cenas vinculam-se, frequentemente, às quatro personagens jovens, ou aos dois pares: Berta e Miguel, moradores dos arredores, e Linda e Afonso, habitantes da casa-grande. O relacionamento entre os dois casais representantes dos espaços polarizados é marcado por grande tensão, causada, em grande parte, pela afinidade existente entre essa esfera do livro e o enredo amoroso dos romances urbanos alencarinos. A impossibilidade da materialização de um enredo sentimental - flertes, paixões, complicações amorosas, casamento -, que é esboçado, mas esvaziado, pois não se sustenta no ambiente social da fazenda, faz com que, nessas cenas, o tom do narrador se torne instável e a sua parcialidade apareça de forma mais clara. Ao assumir as contradições do mundo da fazenda, Alencar, no Til, afasta-se da reconciliação típica do folhetim romântico.

\section{A PAISAGEM ASSOMBRADA}

A indecisão do romance em relação ao seu cenário principal provoca uma anomalia interessante. Se em O Guarani a abertura do romance apresenta o solar dos Mariz, em Til, na impossibilidade de escolher um núcleo, a abertura se dá em um território neutro e mediano, a periferia próxima da fazenda, os seus limites. No entanto, ao longo do livro, o narrador vai apresentando cada uma das moradias das personagens principais do romance: a Fazenda das Palmas, a casa de Berta, a casa de Zana e a furna de Jão Fera. Em cada uma dessas apresentações temos a impressão de que o romance está recomeçando, pois o narrador apresenta a casa da personagem de uma forma característica das aberturas, com a localização precisa de um espaço e de um tempo.

O Til é dividido em quatro partes. A primeira trata da fazenda; a segunda trata dos seus arredores e se abre com a descrição da casa de Berta: "Na entrada do vale, onde assenta a freguesia de Santa Bárbara, via-se outrora à margem do Piracicaba, escontra o rio, um velho casebre" ${ }^{27}$. A apresentação dessa esfera - espacial e social - do romance, além de funcionar como uma segunda abertura, traz em germe um aspecto que se desenvolverá ao longo da descrição e que reflete a postura do narrador em relação ao mundo da periferia do latifúndio escravista, aspecto que desembocará na atmosfera lúgubre e melancólica que será uma das marcas do romance. Trata-se dos termos “outrora" e "velho". O parágrafo seguinte, que descreverá com minúcias as características da fachada do casebre, reitera a ideia de antiguidade: "Era uma antiga construção de taipa”.

Se comparamos essa apresentação de um cenário importante do romance com aquela da Fazenda das Palmas, nota-se uma mudança na percepção do tempo por

27 ALENCAR, José de, op.cit., p. 734 . 
parte do narrador. O momento tratado é o mesmo, I846, o presente da narrativa; a distância em relação ao tempo de onde fala o narrador, portanto, também é a mesma. No entanto, quando fala da fazenda, o "outrora" usado na apresentação do "velho casebre" é substituído por: "Em I846, era de recente fundação a fazenda das Palmas"28. O narrador afirma, em seguida, que a fazenda fora construída em local onde antes havia "um velho casebre de caipira, dois cafezais e alguma pouca roça", sugerindo que, soterrada pela produtividade da fazenda, existe a ruína de um casebre. A antiguidade dos arredores desdobra-se, à medida que a descrição segue, na sensação de abandono e ruína. As laranjeiras, ao lado do casebre, são "encarquilhadas"; há no canteiro, “couves gigantes, já com pretensões de arbustos, de tão velhas que eram”. O cavalo é magro; a galinha sura - que dá nome ao capítulo - teve os pés roídos pelos ratos, e sobrevive graças ao desvelo de Berta. A menina cuida, também, de um burro em "mísero estado": "De magreza extrema [...], era propriamente uma carcaça [...]. A outra orelha, [...] a perdera ele na mesma ocasião em que de uma foiçada lhe vazaram o olho esquerdo, levando-lhe boa parte da cabeça”29.

A atmosfera que envolve a cena ressalta ainda mais a violência descrita: "Vistas através do véu, as árvores tomavam um aspecto pavoroso e fantástico, e às vezes figuravam os espectros, de que a abusão povoa os ermos, a fugirem espancados com os primeiros albores do dia" ${ }^{30}$. $\mathrm{O}$ ambiente lúgubre da cena lembra muito o dos romances góticos ingleses. $\mathrm{O}$ que poderia ser uma cena rural que mostrasse os afazeres matinais de Berta, no trato com as criações, transforma-se em um passeio por um mundo devastado, habitado por seres aleijados, vítimas de violência extrema. Na continuação da cena, o leitor acompanha a menina até a casa de Zana, a velha escrava louca, que se apresenta como mais um dos seres mutilados que são alimentados e cuidados por Berta.

Em Como e Porque Sou Romancista, Alencar aponta dois modelos de romance que o teriam influenciado e estariam na base de sua formação: um deles é o romance gótico; o outro, um romance pitoresco e solar que se abre "em uma campina marchetada de flores" ${ }^{\text {I }}$. O Til - cuja primeira cena se passa em uma "rechã" iluminada por um "sol esplêndido" e coberta de "açucenas escarlates" - parece ser um romance em que Alencar usou os dois moldes. A cena de que estamos tratando apresenta, de forma bem dosada, essa mistura, caso raro no romance, que na maioria das vezes tende mais ao confronto de aspectos díspares. Nesse caso, a dualidade formal característica do livro está amalgamada de forma harmônica. Para essa impressão, muito contribui o tratamento dado à descrição da paisagem e a escolha do amanhecer, momento intersticial. Com isso, a névoa não afronta a verossimilhança, uma vez que madrugar na roça é comum, e o pitoresco da cena mantém-se em paralelo a sua melancolia tendente ao macabro.

\footnotetext{
28 Idem, p.702. Grifos meus.

29 Idem, p.736. As citações do parágrafo estão na p. 734 .

30 Idem, p.734.
}

3I ALENCAR, José de. Como e Porque Sou Romancista. In: Obra Completa, Rio de Janeiro, Aguilar,

I959, v. I, p. I36. 
O aspecto sombrio aumenta quanto mais a descrição se afasta da casa-grande. Depois de sua apresentação, o narrador nos descreve a Ave Maria, o mencionado ponto das emboscadas, que funciona como contraponto da casa-grande e paradigma dos arredores sombrios: "Não obstante ser o caminho em toda a sua extensão, desde a extrema da fazenda, coberto e sombrio, havia contudo um lugar, cujo torvo aspecto correspondia ao terror supersticioso que inspirava e à sinistra reputação que adquirira" ${ }^{2}$. Note-se que o narrador demarca bem o espaço e informa que, a partir do limite da Fazenda das Palmas, a atmosfera é sombria. É interessante o modo pelo qual, na descrição da natureza, aspectos objetivos da paisagem vão sendo contaminados por uma dimensão sobrenatural, que, por sua vez, se relaciona com a violência daquela sociedade.

Esse tratamento da paisagem foi forjado no romance gótico inglês, surgido no fim do século XVIII e diretamente vinculado à Revolução Francesa e à conturbada atmosfera mental da época33. O gótico ordena, na descrição da natureza, "aspectos inquietantes da Cultura ou da História”34. É essa inquietação que estamos tentando apontar em Til, vinculando-a aos espaços periféricos da fazenda. No caso da descrição do sítio das emboscadas, o assunto inquietante é explicitado e nomeado, uma vez que o lugar é palco de assassinatos. No entanto, a violência latente no romance não é só a violência específica da prática das tocaias e da "justiça” feita na esfera privada, fora das instituições legais; é também um mal não nomeado, que se espraia por vários níveis do romance. A importância do espaço na economia simbólica dos enredos góticos está vinculada a "coisas mal resolvidas, espectros, recordação obsessiva e lugares mal-assombrados" ${ }^{35}$, aspectos presentes em Til, e que apontam, como tudo indica, para a escravidão.

Um tema comum ao Til e aos romances góticos é o da culpa pregressa, que ronda as novas gerações e funciona no enredo como um segredo que só será revelado no final. Essa culpa deve ser redimida pela heroína, que "funciona como uma espécie de mártir, necessária à conversão do Mal no Bem"36. Além disso, no gênero gótico, o poder patriarcal é criticado como forma arcaica de poder pessoal e abusivo que deve ser transformado. No romance gótico - como no Til - a violência patriarcal é representada como uma culpa a ser expiada e que determina o assombramento do mundo. Enquanto essa culpa pairar sobre ele, a vida não seguirá, o tempo será travado.

Em Til, o modo pelo qual Alencar desenvolve o tema da culpa do senhor da casa-grande faz com que, embora de forma oblíqua, esta se relacione à violência da escravidão. No romance gótico, a culpa vincula-se ao vilão, figura demoníaca que

32 ALENCAR, José de, op.cit., p. 703.

33 PRAZ, Mario. La "Novela Gótica” de M. G. Lewis. In: . El Pacto com la Serpiente - Paralipómenos de

"La Carne, la Muerte y el Diablo en la Literatura Romántica”. Tlalpan, Fondo de Cultura Econômica, I988, p 26. 34 SÁ, Daniel Serravalle de. Gótico Tropical: o Sublime e o Demoníaco em O Guarani. Dissertação de mestrado, São Paulo, Faculdade de Filosofia, Letras e Ciências Humanas da Universidade de São Paulo, 2006, p. II.

35 VASCONCELOS, Sandra Guardini. Dez Lições sobre o Romance Inglês do Século XVIII. São Paulo, Boitempo, 2002 , p. I08.

36 Idem, p. Io9. 
encarna o mal. No romance alencarino, esse papel é vivido por Ribeiro, personagem estereotipada e opaca, cujas ações são sempre perversas. No entanto, por um estranho deslocamento - que no romance acontece várias vezes - Luís Galvão, além de ser vítima da vingança de Ribeiro, funciona também como um duplo deste, uma vez que compartilha com ele, na economia do enredo, a culpa pelo assassinato de Besita, a mãe de Berta. O narrador, como já vimos, é condescendente com Luís Galvão e evita acusações, mas, no livro, o peso da culpa recai todo sobre o fazendeiro, que tem que purgar a culpa, confessando-a publicamente. É como se, por meio de Ribeiro, fosse possível tratar da culpa do senhor da casa-grande sem chocar o leitor.

Violência e barbárie estão na base das relações sociais em uma sociedade escravocrata. Essa violência é de difícil expressão e tema tabu. Alencar, como se sabe, já tratara da escravidão urbana e doméstica nas peças Mãe e O Demônio Familiar, mas ao tratar da escravidão no espaço rural - na grande fazenda de café - passa a figurar a escravidão de uma nova maneira. Em $O$ Tronco do Ipê, a violência e as fantasmagorias existem, mas são bem localizadas, o que faz com que não contaminem todas as dimensões da obra. A questão do trabalho que, como vimos, projeta em Til uma ambiguidade problemática, em $O$ Tronco do Ipê é mantida sob certo controle, pois a sinhazinha trabalha mais do que os escravos. Em Til, ao contrário, ao assumir a dicotomia dos dois mundos em confronto, a violência de seu embate não mais pode ser dissimulada.

O espaço da fazenda, aliás, tem afinidades evidentes com a violência da escravidão e, em nossa literatura, foi palco de muitas obras que tratam de dor e perversão. Em um levantamento do tema gótico na literatura brasileira, Maurício Cesar Menon percebe que o tema, em seu desenvolvimento nacional, aparece principalmente nos romances regionalistas. Segundo o autor, muitas vezes, nessas obras, "a aristocracia dos vilões góticos cede lugar [...] aos grandes latifundiários e aos senhores de escravos”37.

A figuração da violência da escravidão de forma direta em nossa literatura foi tardia. Gonçalves Dias, em Meditação (I849), descreve a escravidão como realidade material que sustenta o país - "vi somente escravos. [...] o alimento de todos os seus habitantes é comprado à custa do sangue do escravo" 38 - e, também, como "maldição que passa de pais a filhos" 39 . O eu lírico "sobrevoa" o Brasil, tendo uma visão abrangente de tempo e espaço. No presente, descreve a escravidão: "Seguia com avidez as visões, que se me ofereciam aos olhos, como uma fantasmagoria tenebrosa; [...] E uma voz retumbante me gritava aos ouvidos - 'vê' - e eu continuava a fixar o espetáculo doloroso" ${ }^{\circ}$.

A visão dolorosa, "fantasmagoria tenebrosa", é de difícil aceitação e conspurca a realidade. Gonçalves Dias não tratará diretamente do tema em sua obra lírica, de temática indianista. Duas décadas depois, Castro Alves o expõe de forma explícita,

37 MENON, Maurício Cesar. Figurações do Gótico e de Seus Desmembramentos na Literatura Brasileira - de I843 a I932. Tese de doutorado, Londrina, Universidade Estadual de Londrina, 2007, p. I3I.

38 GONÇALVES DIAS. Meditação. In: . Obra Completa. Rio de Janeiro, Nova Aguilar, I998, p. 727.

39 Idem, p. 726.

40 Idem, p. 727. 
em sua poesia. Em “Ao Romper d’Alva”, de Os Escravos, o grito da escravidão macula a natureza virgem:

Oh! Deus! Não ouves dentre a imensa orquestra

Que a natureza virgem manda em festa

Soberba, senhoril!

Um grito que soluça aflito, vivo,

O retinir dos ferros do cativo,

Um som discorde e vil? ${ }^{4 I}$

O "grito" da poesia de Castro Alves remete aos dois gritos de Brás, na cena em que o narrador tenta encenar um idílio entre os quatro jovens, e na qual aparece, pela primeira vez, o título do livro, ainda de forma enigmática, pois o leitor não sabe que se refere a Berta:

Súbito no mato soou um grito bravio, e logo a voz estranha, ao mesmo tempo saturada de dor e impregnada de sarcasmo, lançou em uma gama estridente este clamor incompreensível: — Til! ... Til! ... Til! ... Ó Til! ...42

[...]

Nesse momento, soou de novo o mesmo estranho clamor que antes se ouvira; mas desta vez gania a voz com tal ímpeto e frenesi que estrangulava-se.

— Til! Til! Til! ...43

Cada um dos gritos é contíguo a duas cenas do romance em que os escravos estão na lavoura. Estas, por sua vez, emolduram a cena do encontro dos jovens. Assim, é possível fazer uma relação entre "o som discorde e vil" da poesia de Castro Alves - "o retinir dos ferros do cativo" - e o clamor estridente que atrapalha o idílio. Ao mesmo tempo que o narrador afirma que o clamor é "estranho e incompreensível”, ele é formado pelo próprio título do livro - Til -, o que faz com que a polarização problemática de centro e periferia - ou importância e desvalorização - se anuncie uma vez mais. Ou seja, o grito que dá nome ao romance, o que indica importância e essencialidade, é, ao mesmo tempo, ignorado pelo narrador e pelos fazendeiros.

Essa cena - muito importante na economia do romance, tendo como cenário os limites da fazenda e apresentando os protagonistas jovens representantes dos dois polos figurados no livro - aponta para a ambiguidade provocada pela coexistência de dois núcleos em confronto. A indecisão entre os dois polos leva a uma instabilidade estrutural e à indiferenciação, presente em várias instâncias do romance, desde as mais superficiais até o núcleo mais secreto e essencial, seu ponto de vista, que se projeta sobre toda a estrutura, desdobrando-se em figurações de duplos e de transes. $\mathrm{Na}$ esfera das personagens dependentes reina o descontrole e a frágil autonomia do

4I CASTRO ALVES. Obra Completa, Rio de Janeiro, Nova Aguilar, I976, p. 2 I6.

42 ALENCAR, José de, op.cit., p. 722.

43 Idem, p. 727. 
sujeito, sendo essas personagens suscetíveis a transes, que vão desde as convulsões epiléticas de Brás, Zana e Jão, até as fusões de Berta e Jão com outros seres ${ }^{44}$.

Para exemplificar a ampla proliferação de duplos no romance temos, nas personagens, os nomes que se repetem de geração para geração, e, mais do que isso, as personagens revivem os mesmos papéis, porque o enredo do presente repete $o$ da geração anterior. Acresce que Berta e a mãe são idênticas e têm o mesmo nome. Assim, o enredo do livro se repete, e a cena do assassinato de Besita - eternizada na pantomima de Zana, de que trataremos a seguir - é revivida no presente da narrativa, tendo Berta no lugar da mãe. De resto, ela continua igual: o mesmo local, o mesmo assassino, a mesma testemunha e, de certa forma, a mesma vítima. É, aliás, nessa esfera que se encontra o duplo do narrador: Zana, a velha escrava, é a guardiã do segredo do enredo, e sua figura sistematiza toda a ambiguidade do ponto de vista do romance. De forma paralela ao narrador que representa o mundo da casa-grande, um narrador mudo conta, à sua maneira, a história que o outro tenta dissimular.

\section{NA CASA DE ZANA}

O espaço da casa de Zana é paradigma da dialética problemática entre centro e periferia que tensiona o romance. Espaço em ruínas, ignorado pela comunidade, guarda, no entanto, o segredo do enredo do livro e do passado de sua personagem central. A velha escrava enlouquecida pelo terror é a guardiã desse passado e testemunha da violência que funda a comunidade e, embora demente, a única que tem consciência dos perigos que rondam a heroína.

Se nos lembramos de que a descrição do casebre de Zana se dá na continuação da cena que descreve o casebre de Berta - cena que, por sua vez, como já vimos, faz um contraponto à descrição da casa-grande -, percebemos o percurso de uma gradação decrescente: da riqueza e produtividade do espaço da casa-grande, passando pela pobreza improdutiva da casa de Berta, até a ruína que abriga Zana: "Atrás de um fraguedo, cuja falda atravessava o leito do rio, abrolhando-lhe a corrente, existia naquele tempo uma casa em ruínas. [...] Da cozinha [...] saía um som roufenho e soturno [...]. Acocorada a um canto, descobria-se uma criatura humana, dobrada sobre si a modo de trouxa" 45 .

Se há em todo o romance a correlação entre espaço e personagens, nessa cena essa característica encontra sua expressão mais radical. No caso de Zana e seu casebre, espaço e personagem misturam-se completamente, e são ambos guardiães de um enigma: "Foi este o pensamento de Berta, que atraída pelo encanto do mistério empenhou-se em perscrutar esse ermo onde jazia no seio de uma casa e de uma consciência, ambas em ruínas, o arcano impenetrável"46.

Apesar de ignorados e renegados pela comunidade, ou talvez por isso mesmo, o espaço em ruína e a figura decrépita da escrava tornam-se centrais para a

44 Cf. PASTA JR., José Antonio. O Ponto de Vista da Morte - uma Estrutura Recorrente da Cultura Brasileira. Revista da Cinemateca Brasileira, n. I. São Paulo, 2012.

45 ALENCAR, José de, op.cit., p. 737.

46 Idem, p. 740 . 
compreensão do enredo. A ruína é palco da encenação da pantomima de Zana. Representação teatral sem palavras, essa pantomima ganha importância por ser a narração de um evento que já aconteceu e que se repetirá no enredo do romance, tendo, dessa vez, o leitor como testemunha. A atualização do enredo da pantomima no presente da narrativa faz de Zana uma guardiã legítima de um dado essencial daquela realidade. Essa dimensão do romance - espaço, personagem e cena diferencia-se por sua característica pictórica com forte repercussão simbólica na economia do livro: quadro estático, que se repete sempre o mesmo, miniatura do passado, a pantomima de Zana exige decifração. Assim como Berta, o leitor também é posto na situação de desvendador de um enigma, enquanto o autor vai dando pistas que remetem à escravidão, embora, em um primeiro nível de significação, o enredo da pantomima aponte para um caso particular. Como já vimos, a cena em pauta é precedida pela descrição do percurso da menina em um espaço povoado de seres mutilados e violentados, entre os quais, Zana, que assim se apresenta como mais um desses seres devastados, o que dá ao destino da velha escrava um valor coletivo. A violência da escravidão não é mostrada de forma direta em Til, mas a personagem Zana evidencia suas consequências, mesmo que de forma oblíqua: mais importante do que o caso específico daquele assassinato, a pantomima narra a história de uma grande violência que vitimou uma escrava.

O Til trata da perversidade da escravidão e da situação vulnerável dos homens pobres e livres em um mundo onde os escravos são a base da produção. Os escravos são descritos como coadjuvantes do mundo da fazenda. Alguns são nomeados: a escrava do eito Florência, o pajem Faustino, a mucama Rosa, o preto velho, Pai Quicé, o escravo africano Monjolo, o mulato Amâncio, as velhas escravas, Fausta e Zana. Faustino e Monjolo participam do atentado à vida do fazendeiro na noite de São João; Rosa e Florência se engalfinham na mesma noite. Em vez de serem mostrados como vítimas da violência, os escravos jovens são descritos em cenas que ressaltam a sua própria violência. Em grupo, aparecem em quatro cenas, duas no eito e duas festejando. Das cenas do eito, uma se passa na hora do almoço e a outra mostra os escravos trabalhando sob a supervisão de um feitor, cantando uma música que o satiriza. O narrador chama a atenção tanto para a agressão verbal dissimulada dos escravos quanto para a tolerância bonachona do feitor. Se a violência contra os escravos não é descrita diretamente, vemos a atmosfera sombria e descontrolada do romance vincular-se à violência e às contradições da escravidão, se seguimos as pistas deixadas pelo autor e deciframos os enigmas e charadas do enredo.

\section{O ACALANTO DA ESCRAVIDÃo}

Na cena em que os escravos trabalham, na primeira parte, eles cantam. Nas outras três partes, há sempre uma canção cantada por um escravo, cada uma delas registrada graficamente de forma diferente do restante do texto, com as estrofes e as rimas em evidência. No caso da cena da casa de Zana, na segunda parte, a cantiga é cantada primeiro por Berta e depois pela escrava, que a ensinara à menina: 
Cala a boca, anda, nhazinha,

Ai-huê, lê-lê!

Senão olha, calhambola,

Ai-huê, lê-lê!

Vem cá mesmo, Pai Zumbi,

Toma, papa nha Bebê!47

Notem-se os motivos africanos do acalanto de Zana e a relação que une as duas personagens: é cantando que Berta consegue se comunicar com a escrava, é cantando que Zana acalenta o Bebê, nome pelo qual Berta é tratada pela escrava, que, como o leitor saberá mais tarde, pintara, em I826, o corpo da menina com carvão, para que Ribeiro não soubesse que Besita tinha uma filha, em uma tentativa de evitar o assassinato de sua "filha de leite" e senhora. Esse episódio é central tanto na pantomima de Zana quanto no flashback, e nos interessa por mostrar a relação de Berta com a escravidão. De alguma forma, Berta é também filha de uma escrava, já que é assim que é representada na pantomima: o bebê preto ninado por Zana.

Tanto a cantiga quanto a pantomima ganham no romance estatuto de enigma e exigem de Berta, para sua decifração, atenção cuidadosa. O mesmo acalanto será repetido por Zana, na terceira parte, com pequenas variações, o que marca ainda mais seu caráter enigmático. O que tentamos mostrar aqui é a afinidade entre a pantomima e a cantiga, em seu aspecto tanto de uma expressão artística popular, quanto de miniatura autônoma que se repete muitas vezes com pequenas variações. É como um refrão que pontua o romance, refrão entoado pelos que não têm voz naquela sociedade. Esse ritmo repetitivo impede que o enredo siga da forma linear característica dos romances. No espaço que faz contraponto à casa-grande - este sim o lugar ideal para o desenvolvimento de um romance sentimental - não há lugar para o tempo linear e histórico, nem para o realismo. A casa em ruínas e a escrava enlouquecida são entraves no romance e, ao mesmo tempo, como já ressaltado, representam o próprio enredo do livro, o coração da obra.

Nas comemorações de São João, longamente descritas pelo narrador, em todas as esferas sociais da fazenda, há uma cena na qual os escravos dançam um samba. O samba é descrito como "um frenesi que toca o delírio"48, "remexido infernal"49 ao som dos "retumbos soturnos do jongo" 50 . A dança dos escravos é descrita como um transe. Enquanto canta e dança sobre o braseiro, um escravo tem "ímpetos de possesso", o que aproxima a descrição do samba dos escravos de todas as muitas cenas de transe que pontuam o livro. Esta cena é um outro exemplo da convivência de duas dimensões, a princípio excludentes, que participam do romance: a figuração da realidade popular de modo pitoresco e soturno. Além dos escravos, o narrador, que já apresentara a festa de São João no terreiro próximo à casa-grande, passa a descrever a participação dos feitores e camaradas, no terreiro próximo à senzala.

47 Idem, p. 738.

48 Idem, p. 824.

49 Idem, p. 824 .

50 Idem, p. 823. 
Um dos camaradas "arranha na viola uma chula" "I. O fato de os escravos e os trabalhadores da fazenda se expressarem muitas vezes pela música, pela dança e pela pantomima é uma forma de dar voz aos que não têm voz naquela sociedade, aspecto bem representado pela pantomima de Zana, que conta, para os que a decifram, o segredo mais importante do enredo.

A escravidão e as grandes fazendas de café eram indissociáveis. Sem a mão de obra dos escravos não havia produção. Ao mesmo tempo, o escravo é uma pessoa socialmente morta e portanto sem voz. Em estudo de fôlego que trata da escravidão ao longo da história, tentando, através da comparação, descobrir o cerne do que é ser escravo, Orlando Patterson constata a posição liminar dos escravos que, não sendo párias, pois participam ativamente da produção social, não têm direitos: "o escravo permanecia na sociedade como uma parte dela, mas fora dela" ${ }^{2}$. Essa dimensão liminar, aliás, uma das principais características da posição de escravo, segundo o autor, nos remete à posição dos dependentes em nossa sociedade escravocrata e em nossa literatura: "a escravidão compreendia dois princípios contraditórios, marginalidade e integração" 53 . O autor radicaliza sua conceituação de liminaridade, aproximando-a, ainda mais, do regime do limite, de que já tratamos: "a essência da escravidão é que o escravo, em sua morte social, vive na margem entre comunidade e caos, vida e morte" 54 . Esse limbo social aproxima os dependentes brasileiros dos escravos, e no Til essa constatação se formaliza, seja, no nível do enredo, na convivência dos camaradas, capangas, escravos e feitores nas cenas de terreiro (como essa do samba), seja em uma dimensão alegórica, na aproximação entre Berta e a escravidão, pois ela canta o acalanto dos escravos, o mesmo que a ninara.

O que se trata de explicitar é a impossibilidade de escravos e homens pobres livres terem voz naquela sociedade, assim como o modo pelo qual, em Til, essa falta de voz se transforma, por um lado, na propensão ao transe, e por outro, em novos modos de expressão, muitas vezes dissimulados e enigmáticos, única forma de se comunicarem entre si, longe do controle do senhor. Em seu estudo sobre a escravidão, Patterson constata a relação entre confronto e dissimulação que já verificamos, também, em Til: "o que fazem senhores e escravos é lutar: às vezes de forma ruidosa, mais frequentemente silenciosa" 55 .

O grande número de referências à violência, na cena narrada pela pantomima, principalmente as consequências dessa violência sobre Zana, corroboram a leitura que aponta para a pantomima como alegoria da escravidão: "Devia de ser horrível o espetáculo que ali surgira a seus olhos, porque depois de tantos anos, a só imagem a fulminava. Erigia-se-lhe o corpo hirto; um grito de terror estalava no peito, e vinha estrangular-se nas fauces. Volvia sobre si; e tombava ao chão como uma pedra"56.

5I Idem, p. 824 .

52 PATTERSON, Orlando. Escravidão e Morte Social: um Estudo Comparativo. São Paulo, Edusp, 2008, p. 80.

53 Idem, p. 79.

54 Idem, p. 86.

55 Idem, p. 297.

56 ALENCAR, José de, op.cit., p. 74I. 
Portador de um segredo crucial, o segundo narrador do romance é mudo porque traumatizado por uma violência inominável que o paralisa. A figuração do escravo sem voz, mas que encena com o corpo um segredo decisivo, expõe o lado contraditório do mundo da fazenda. A cena da casa de Zana funciona como uma alegoria fantasmática incrustada no livro e que acolhe, em sua diferença de figuração em relação à maioria das cenas do romance, a dimensão alegórica de Berta e Brás. Tempo cristalizado e, também, ação confinada a um espaço ruinoso, a pantomima de Zana tem como característica essencial sua autonomia repetitiva: autonomia em relação às outras dimensões do romance, à realidade de suas personagens; autonomia de sua repetição diária por vinte anos, independente de testemunho.

É como se esse lugar e essa personagem existissem em outra dimensão, tanto no sentido do mundo social do romance, quanto no de sua forma literária folhetinesca. Outra característica que chama a atenção na pantomima é que ela é composta de movimentos do corpo que, descritos em detalhes, articulam-se de forma racional, descrevendo um trabalho. Os movimentos do trabalho, no entanto, giram em falso, pois são esvaziados em sua efetividade: "Depois de algum tempo empregado na quimérica operação de acender um fogo ausente, a louca foi à prateleira buscar uns cacos de telha que se lhe afiguravam panelas e frigideiras; e fez menção de lavar o trem de cozinha, para preparar a comida"57. Ao encenar um trabalho fantasmagórico, a pantomima condensa de forma exemplar o descompasso entre a importância dos escravos na produção das riquezas e a sua posição de não sujeitos, aspecto que, como temos visto, embasa o romance, projetando a indistinção e a ambiguidade em sua forma.

A pantomima funciona como um módulo de enredo que aponta, em sua contínua reposição, para a noção peculiar do tempo nesse romance. Como se indicou anteriormente, em vez de se dar pela ação contínua e encadeada, própria do tempo histórico, a ação repetitiva remete para o tempo cíclico do mito. Trata-se, na verdade, da mistura dos dois, pois, apesar da repetição, o enredo da pantomima é atualizado e modificado no presente, o que, de certa forma, liberta as personagens de um ciclo violento e inexorável, destino fatal que cabe aos homens no mundo do mito. O desfecho do livro, no entanto, não resolve o problema da cisão entre a elite e o povo - ao contrário, só a radicaliza -, e a melancolia se mantém. Melancolia que é uma das marcas do episódio da casa de Zana. Tempo e trabalho giram em falso na pantomima, existem e não existem, apontando para o problema de base da sociedade brasileira do Segundo Reinado, a escravidão. Por um momento, ao assistir atentamente à pantomima, a menina Berta transforma-se em alegoria da pátria melancólica, incapaz de entender o enigma de sua história e o nó que a atormenta. $\mathrm{Na}$ cena, Alencar representou o impasse daquele momento histórico, que deixava mais à mostra nossas contradições e prefigurava o fim do Império. 


\section{SOBRE A AUTORA}

PAULA MACIEL BARbOSA pesquisadora de pós-doutorado vinculado ao Programa de Pós-Graduação em Teoria Literária e Literatura Comparada da Faculdade de Filosofia, Letras e Ciências Humanas da Universidade de São Paulo. Bolsista do Programa Capes/PNPD.

E-mail: paulamacielbarbosa@usp.br

\section{REFERÊNCIAS BIBLIOGRÁFICAS}

ALENCAR, José de. Como e Porque Sou Romancista. In: Obra Completa, Rio de Janeiro, Aguilar, I959, v. I. Til . In: Obra Completa. Rio de Janeiro, Aguilar, I965, v. III.

BARBOSA, Paula Maciel. O Idílio Degradado: um Estudo do Romance Til, de José de Alencar. Tese de doutorado em Literatura Brasileira, São Paulo, Faculdade de Filosofia, Letras e Ciências Humanas da Universidade de São Paulo, 20I2.

CANDIDO, Antonio. Os Três Alencares. In: Formação da Literatura Brasileira. Belo Horizonte, Rio de Janeiro, Itatiaia, I993.

CASTRO ALVES. Obra Completa, Rio de Janeiro, Nova Aguilar, I976.

CHAlHOUB, Sidney. Machado de Assis, Historiador. São Paulo, Companhia das Letras, 2003. GONÇALVES DIAS. Meditação. In: . Obra Completa. Rio de Janeiro, Nova Aguilar, I998.

HOLANDA, Sérgio Buarque. Crise do Regime. In: . (Org.). História Geral da Civilização Brasileira,

São Paulo, Difel, I969, t. II, v. 5.

MAGALHÃES JR., Raimundo de. José de Alencar e Sua Época. Rio de Janeiro, Civilização Brasileira, I977. MARCO, Valéria de. A Perda das Ilusões: o Romance Histórico de José de Alencar. Campinas, Unicamp, I993. MENON, Maurício Cesar. Figurações do Gótico e de Seus Desmembramentos na Literatura Brasileira

- de I843 a I932. 2007. Tese de doutorado, Londrinha, Universidade Estadual de Londrina, 2007. OTSUKA, Edu Teruki. Espírito Rixoso: para uma Interpretação das Memórias de um Sargento de Milícias. São Paulo, Revista do IEB, n. 44, p. I05-I24, fev. 2007.

PASTA JR., José Antonio. O Ponto de Vista da Morte - uma Estrutura Recorrente da Cultura Brasileira. Revista da Cinemateca Brasileira, n. I. São Paulo, 2012.

. O Romance de Rosa: Temas do Grande Sertão e do Brasil. Novos Estudos CEBRAP, n. 55, São Paulo, nov. I999.

Volubilidade e Ideia Fixa (o Outro no Romance Brasileiro). Sinal de Menos. Ano 2, n. 4, 2010.

PATTERSON, Orlando. Escravidão e Morte Social: um Estudo Comparativo. São Paulo, Edusp, 2008. PIMENTEL, Osmar. Um Inventor de Mundo Novo. In: Alencar, José de. Til - Romance Brasileiro. Rio de Janeiro, José Olympio, I955 (v. XI das Obras de Ficção de José de Alencar).

PRAZ, Mario. La “Novela Gótica” de M. G. Lewis. In: . El Pacto com la Serpiente-Paralipómenos de "La

Carne, la Muerte y el Diablo en la Literatura Romántica”. Tlalpan, Fondo de Cultura Econômica, I988. RICUPERO, Bernardo. O Romantismo e a Ideia de Nação no Brasil (I830-I870). São Paulo, Martins Fontes, 2004.

SÁ, Daniel Serravalle de. Gótico Tropical: o Sublime e o Demoníaco em O Guarani. Dissertação de 
mestrado, São Paulo, Faculdade de Filosofia, Letras e Ciências Humanas da Universidade de São Paulo, 2006.

SCHWARZ, Roberto. Ao Vencedor as Batatas. São Paulo, Duas Cidades, 1992

_. Um Mestre na Periferia do Capitalismo. São Paulo, Duas Cidades, I998.

.Um Seminário de Marx. In:__. Sequências Brasileiras. São Paulo, Companhia das Letras, I999.

TREECE, David. Exilados, Aliados, Rebeldes - o Movimento Indianista, a Política Indianista e o Estadonação Imperial. São Paulo, Nankin/Edusp, 2008.

VASCONCELOS, Sandra Guardini. Dez Lições sobre o Romance Inglês do Século XVIII. São Paulo, Boitempo, 2002.

VERÍSSIMO, José. História da Literatura Brasileira. Rio de Janeiro, Francisco Alves, I929. 